\title{
Assembling places and persons: a tenth-century Viking boat burial from Swordle Bay on the Ardnamurchan peninsula, western Scotland
}

\author{
Oliver J.T. Harris ${ }^{1, *}$, Hannah Cobb ${ }^{2}$, Colleen E. Batey ${ }^{3}$, \\ Janet Montgomery ${ }^{4}$, Julia Beaumont ${ }^{5}$, Héléna Gray ${ }^{6}$, Paul Murtagh ${ }^{7}$ \\ $\&$ Phil Richardson ${ }^{8}$
}

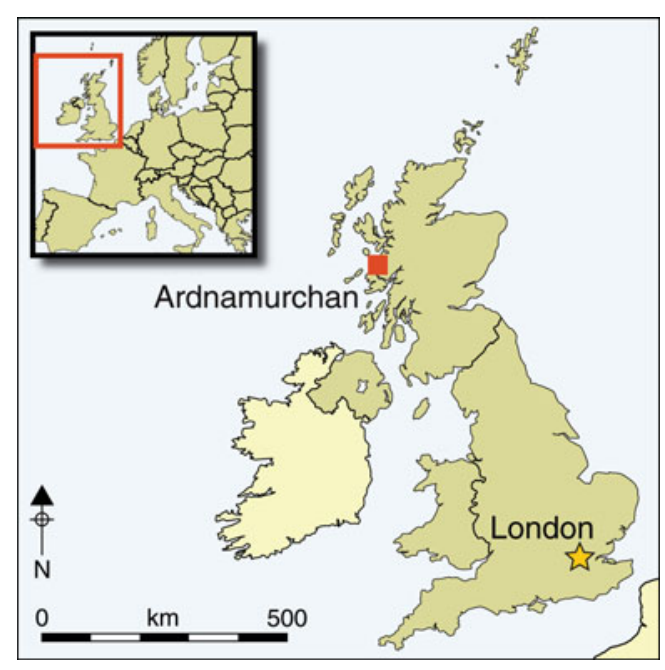

$A$ rare, intact Viking boat burial in western Scotland contained a rich assemblage of grave goods, providing clues to the identity and origins of both the interred individual and the people who gathered to create the site. The burial evokes the mundane and the exotic, past and present, as well as local, national and international identities. Isotopic analysis of the teeth hints at a possible Scandinavian origin for the deceased, while Scottish, Irish and Scandinavian connections are attested by the grave goods. Weapons indicate a warrior of high status; other objects imply connections to daily life, cooking and work, farming and food production. The burial site is itself rich in symbolic associations, being close to a Neolithic burial cairn, the stones of which may have been incorporated into the grave.

Keywords: Scotland, Viking, boat burial, identity, isotopic analysis

School of Archaeology and Ancient History, University of Leicester, University Road, Leicester LE1 7RH, UK School of Arts, Languages and Culture, University of Manchester, Oxford Road, Manchester M13 9PL, UK Department of Archaeology, University of Glasgow, Glasgow G12 8QQ, UK

Department of Archaeology, Durham University, South Road, Durham DH1 3LE, UK

Department of Archaeological Sciences, University of Bradford, Bradford BD7 1DP, UK

Archaeology Services, East Lothian Council, Edinburgh, EH41 3HA, UK

The Clyde and Avon Valley Landscape Partnership, Rosedale Street, New Lanark, ML11 9DJ, UK

- Archaeology Scotland, Stuart House, Eskmills Station Road, Musselburgh EH21 7PB, UK

* Author for correspondence (Email: ojth1@le.ac.uk) 


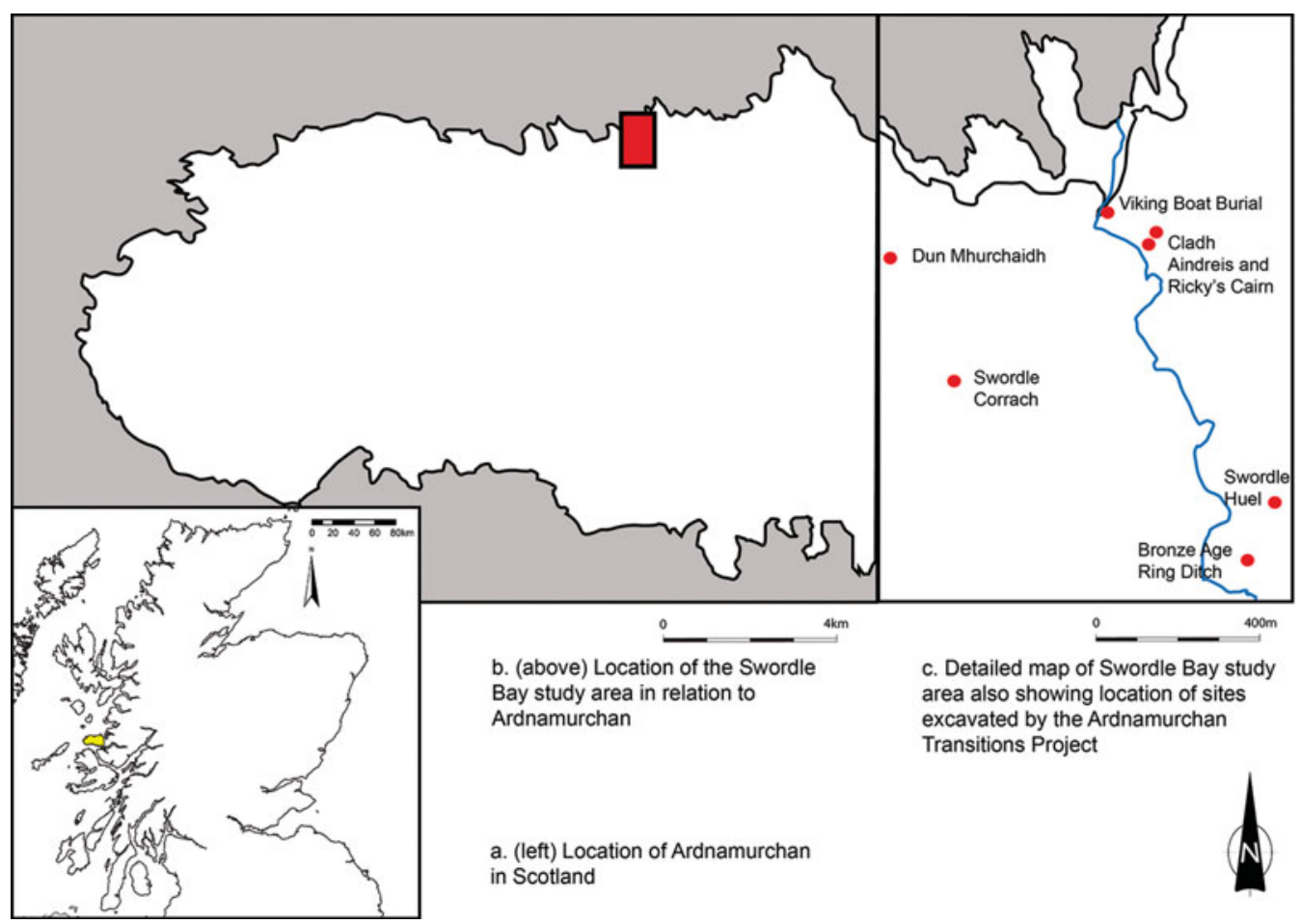

Figure 1. Location map of the Viking boat burial and other sites excavated by the Ardnamurchan Transitions Project.

\section{Introduction}

Viking boat burials are iconic archaeological discoveries. Wonderfully preserved examples discovered at Oseberg and Gokstad in Norway have sparked the imagination, and both archaeologists and the general public remain fascinated by these acts of conspicuous consumption. In the UK, examples are well known from the Scottish islands, including Orkney (e.g. Scar: Owen \& Dalland 1999), Shetland (e.g. Aith, Fetlar: Batey in press) and Colonsay (Kiloran Bay: Anderson 1907), as well as from the Isle of Man (e.g. Balladoole: Bersu \& Wilson 1966). Until recently, however, no intact boat burials had been excavated by archaeologists on the UK mainland. That changed in 2011 when the Ardnamurchan Transitions Project, which examines long-term change on the Ardnamurchan peninsula, western Scotland, discovered and excavated a boat burial in Swordle Bay on the peninsula's north coast (Figure 1). Although not as spectacular in size as some of the Scandinavian examples, it nevertheless represents a rich Viking grave, adding significantly to the corpus of examples from Britain. Dating most probably to the early tenth century AD, the grave assemblage included a rich collection of artefacts.

An interim publication of our findings was made immediately after the excavation (Harris et al. 2012), and here we present the excavation in detail for the first time, alongside the grave goods and isotopic evidence that hint at a possible Scandinavian origin. This burial provides another important insight into the contacts between Scotland, Ireland and (C) Antiquity Publications Ltd, 2017 


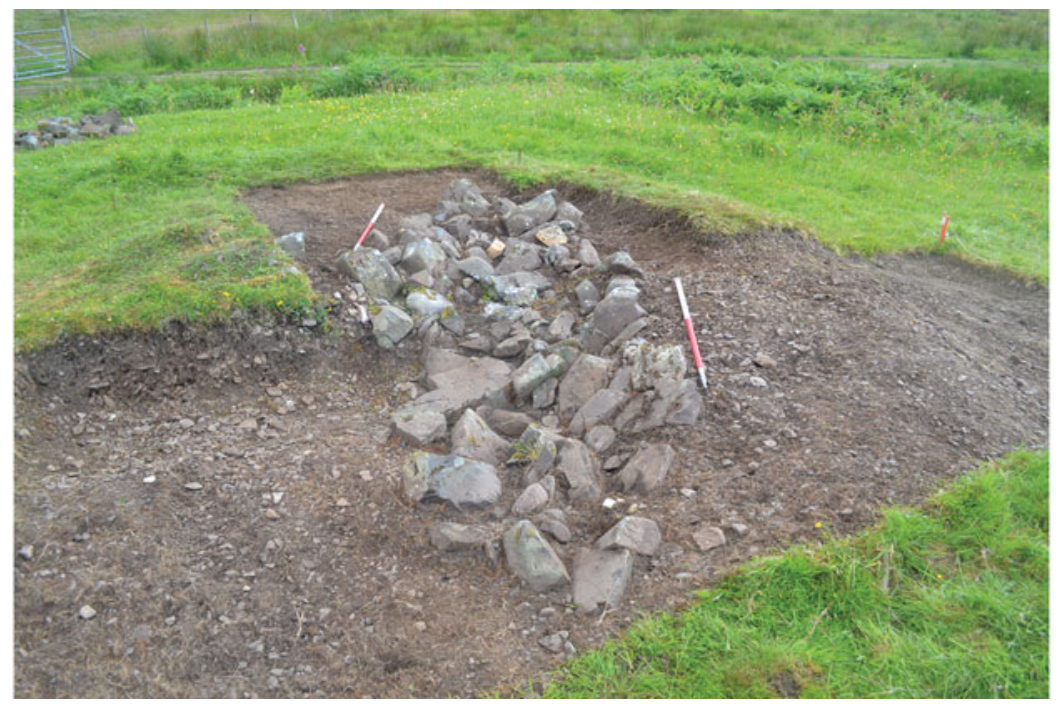

Figure 2. Pre-excavation photograph after initial cleaning.

the Viking homeland in the early tenth century. Furthermore, the assemblage also offers the opportunity to reflect on wider questions around the performance of identity.

\section{The archaeology}

The site was initially recorded as a low-lying mound close to the foreshore, respected by later rig-and-furrow agriculture. Excavation established that the mound itself was natural, with a central, cut feature, within which a substantial number of medium to large stones had been placed in a boat-shaped setting, including two layers of kerbing around the edge of the cut. The arrangement measured $5.2 \times 1.7 \mathrm{~m}$ at its widest point and was orientated west-south-west to east-north-east (Figure 2). A spearhead and shield boss were recovered from amongst the stones, presumably included as part of the process of closing the grave.

At the base of the feature, two finds-rich layers provided extensive evidence for the rivets of a complete, clinker-built boat containing numerous grave goods. These included a sword, an axe, a large ladle containing a hammer and tongs, a drinking horn mount, a ringed pin, a sickle, a whetstone and flint strike-a-lights. Unlike the spear and shield, these items appear to have been placed next to the interred individual. The upper of the two layers also contained two teeth: both molars from the same individual. These were the only identified human remains, the rest of the body having probably decayed in the acidic soil; the location of the teeth suggests the head was towards the west end of the boat.

Turning this archaeological sequence around, we can reconstruct the burial. A boatshaped depression was first cut into a natural mound of beach shingle (Figure 3). After a brief period of silting (perhaps no more than a few hours), the boat was inserted. Into this was placed the body and around it the majority of the finds. Stones were then placed in and around the boat, beginning with two layers of kerbing; the spear and shield were included at this stage. 


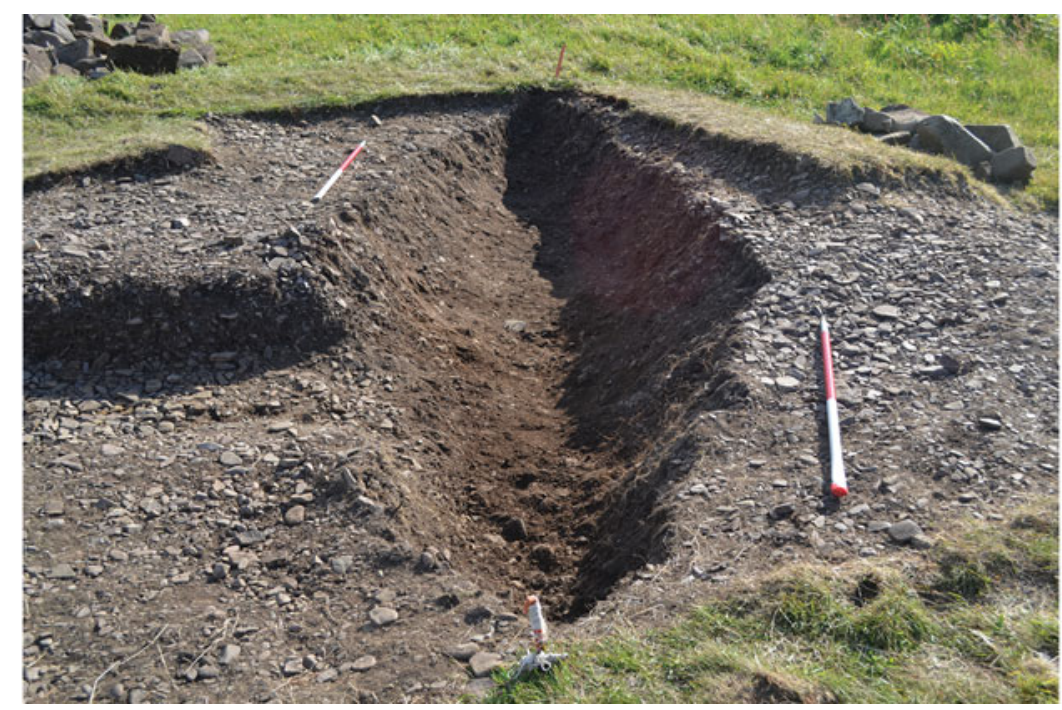

Figure 3. Post-excavation photograph of the cut.

\section{The finds}

The vessel itself survived in the form of 213 rivets recovered in situ and recorded threedimensionally (Figure 4); a handful more had been disturbed. This was clearly an intact craft measuring approximately $5.1 \mathrm{~m}$ in length and would have been a small rowing boat, probably accompanying a larger ship, rather than being a serious sea-going craft. The survival of mineralised wood connected to the decaying rivets should allow further information about the boat to emerge in due course.

Immediately behind the probable location of the head of the buried individual, towards the western end of the boat, was a large iron ladle. The pan was around $270 \mathrm{~mm}$ in diameter with a handle over $0.5 \mathrm{~m}$ long. Various items had been placed within the bowl, including a hammer and a pair of tongs, as well as organic remains, potentially foodstuffs (Greaves 2011). Some mineralised wood fragments also adhered to the base of the ladle, probably representing original boat timbers. The ladle has Scandinavian parallels as well as a more local one at Kiloran Bay on Colonsay, but is not common in a British context (Batey in press).

A number of other artefacts were placed on and around the body itself (Figure 5), including a single copper alloy ringed pin, which may have fastened the burial cloak or shroud (Figure 6). The ring has three bosses, a style that appears to come from Ireland (Graham-Campbell \& Batey 1998: 116), implying southward connections. Between the pin and the ladle was a copper alloy drinking horn rim. Relatively undecorated apart from two simple, incised lines, it could either be insular in origin or may equally have a Scandinavian connection (cf. Paterson et al. 2014: 149-51). The position of the horn suggests it may have been laid to the south (or the right side) of the head.

Other items were found more centrally in the grave, either on the body itself, or interred below it. These included the whetstone, probably of southern Norwegian schist (Askvik (C) Antiquity Publications Ltd, 2017 


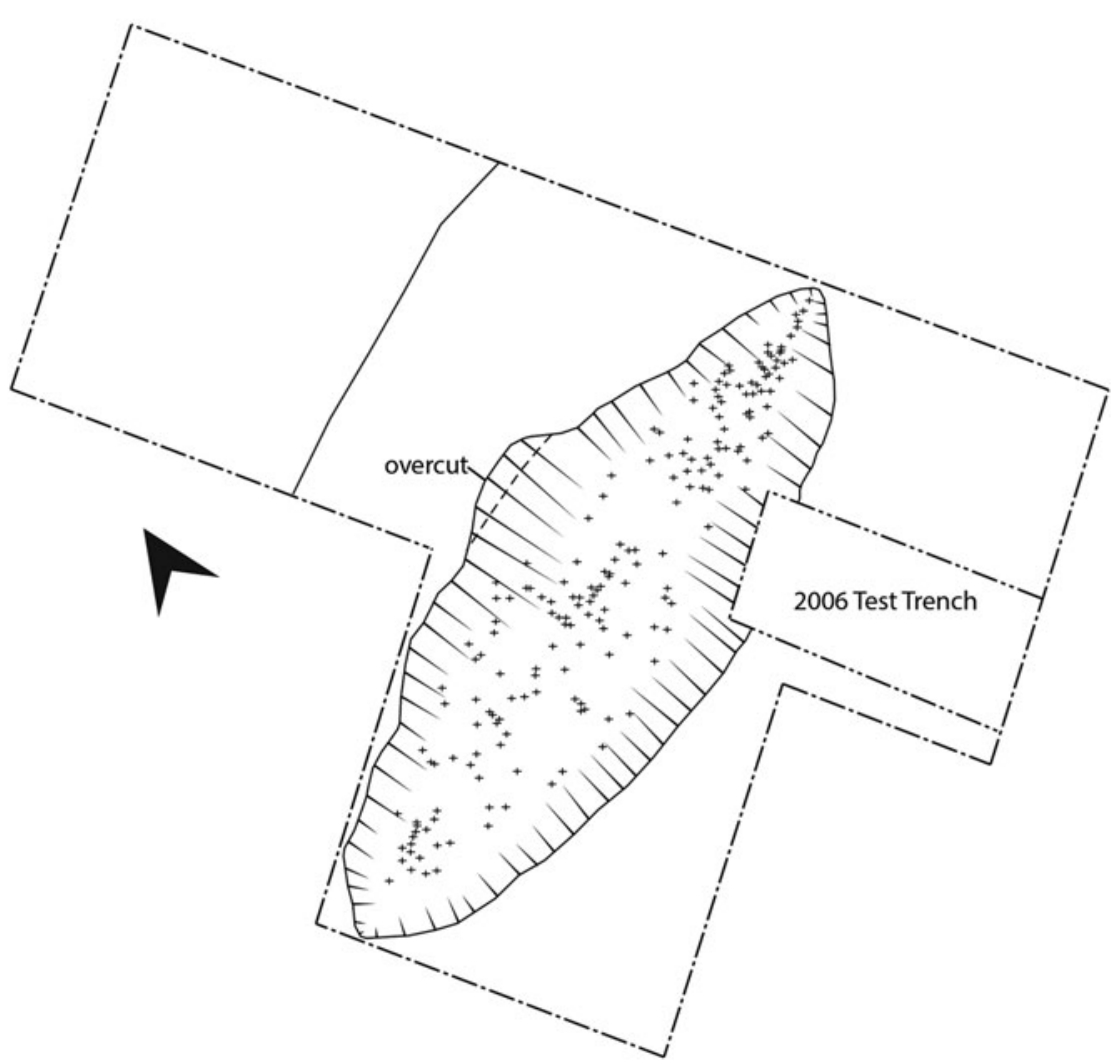

00.250 .5

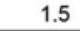

Metres

\section{Legend}

+ Rivet distribution

Figure 4. Plot of the in situ rivets (by Irene Garcia Rovira).

with Batey 2009: 294-95), and the flint strike-a-lights and iron sickle. The latter is paralleled by several examples in Scotland, e.g. from Westness and Pierowall in Orkney (Graham-Campbell \& Batey 1998: 135-37, figs 7.10 \& 7.11) and from Kneep in Lewis (Welander et al. 1987: 151-52, 158-59). There are also many known in Norway, as discussed by Petersen (1951: 515-16), particularly in the west of the country.

Located between the edge of the boat and the north-west (left) side of where the body may have lain was the sword (Figure 7). This appears to have been deposited missing its tip, a feature also noted at Balnakeil in Sutherland (Batey \& Paterson 2013: 637). It had been bent in a shallow S-shape, potentially indicating deliberate damage before depositionsomething we also see with the spear. Around the blade, however, are the remnants of leather 


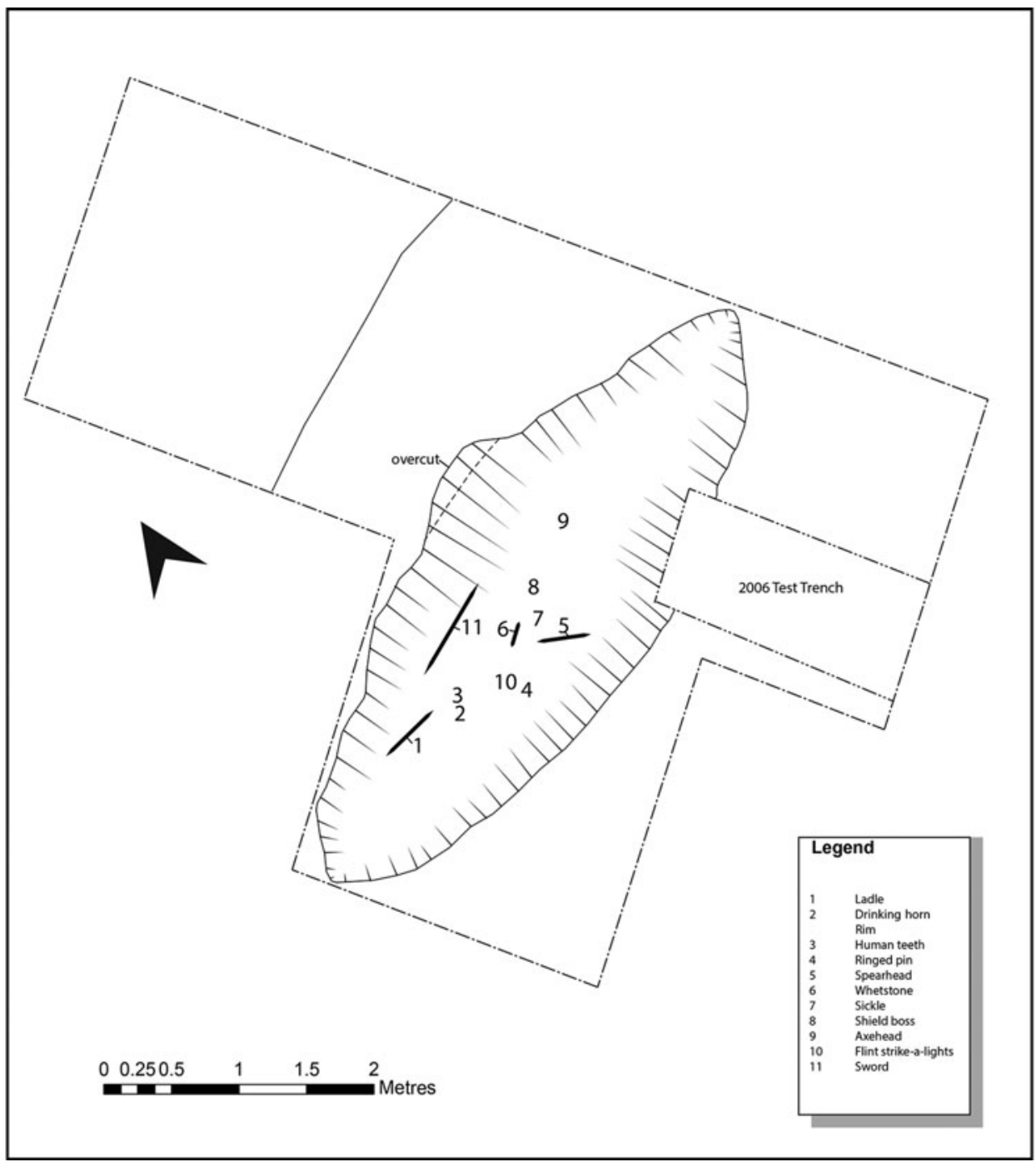

Figure 5. Plot of the major finds recovered from the grave. Note: this is a two-dimensional plan. The spear and shield were higher in the fill than the other finds (by Irene Garcia Rovira).

from a sheath, the presence of which suggests that the change in sword shape took place after deposition. Further investigation of this material is required to resolve this question. Adhered to the sword were mineralised textile remains, either from textile wrapping around the sword and sheath itself, or from the clothes or shroud worn by the deceased, as perhaps paralleled at Scar (Nissan 1999: 109-10). Both the guard and the pommel of the sword are finely decorated with silver and copper wire, and typologically the sword appears to be a Petersen Type K, with suggestions of Type P and Type O (Petersen 1919; Batey in press; Gareth Williams pers comm.). This provides the major evidence that this burial has a terminus post quem of the late ninth or early tenth century AD.

(C) Antiquity Publications Ltd, 2017 


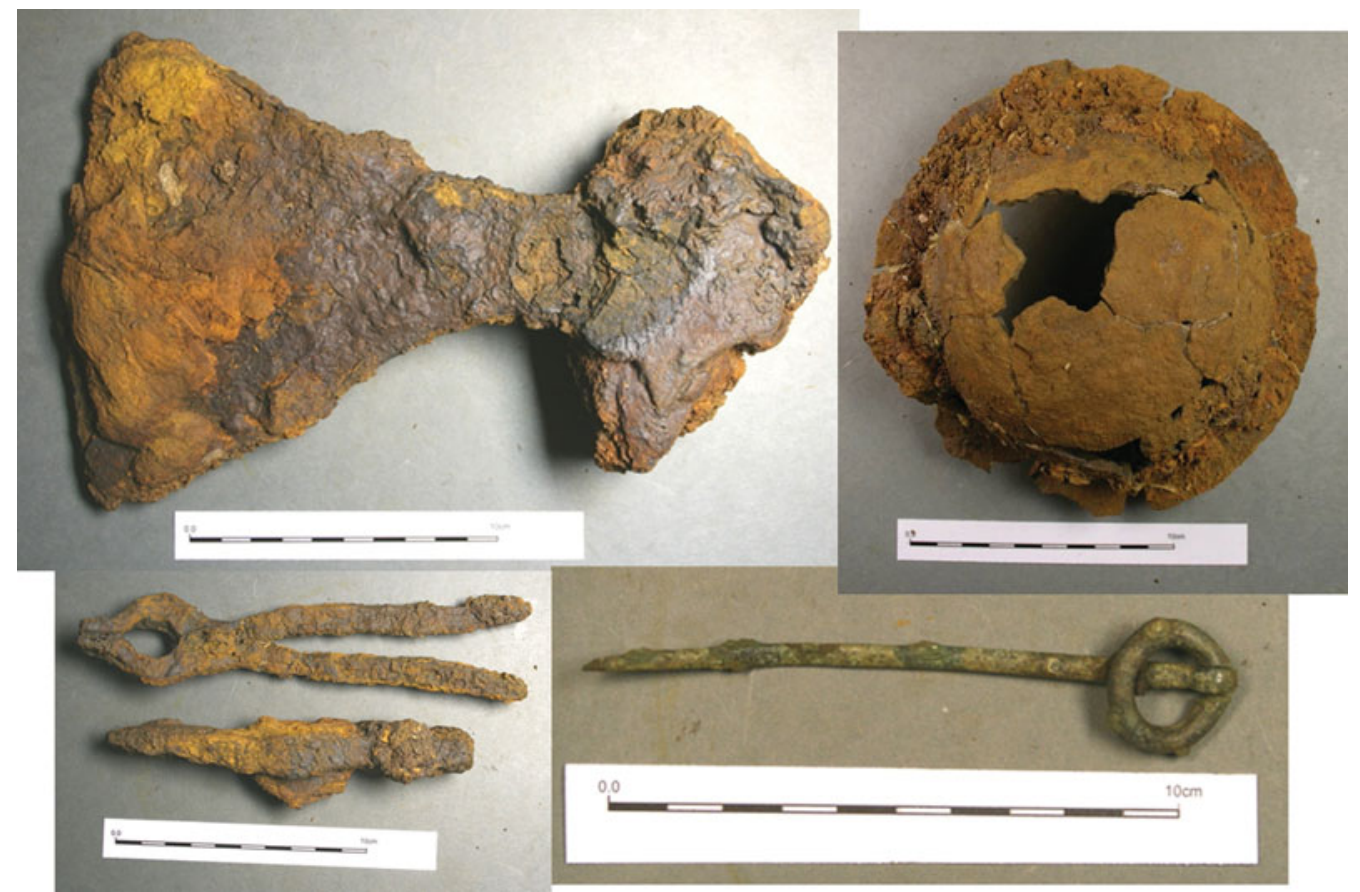

Figure 6. Some of the other finds recovered from the grave (clockwise from the top left): broad-bladed axe, shield boss, ringed pin and the hammer and tongs (photographs: Pieta Greaves/AOC Archaeology).

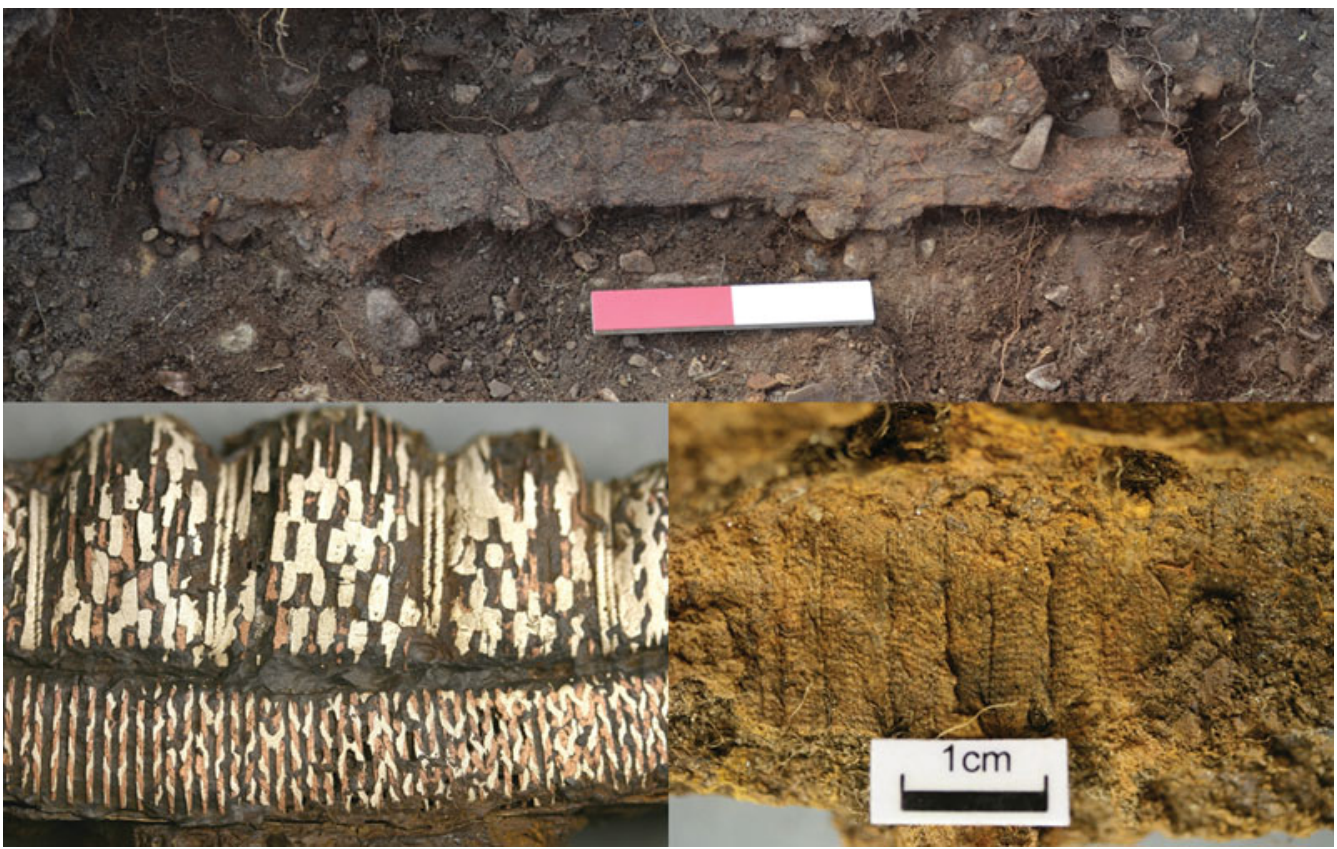

Figure 7. The sword (top); the sword in situ (below); the mineralised textile remains (right); detail of the decoration after conservation (left) (lower photographs: Pieta Greaves/AOC Archaeology). 


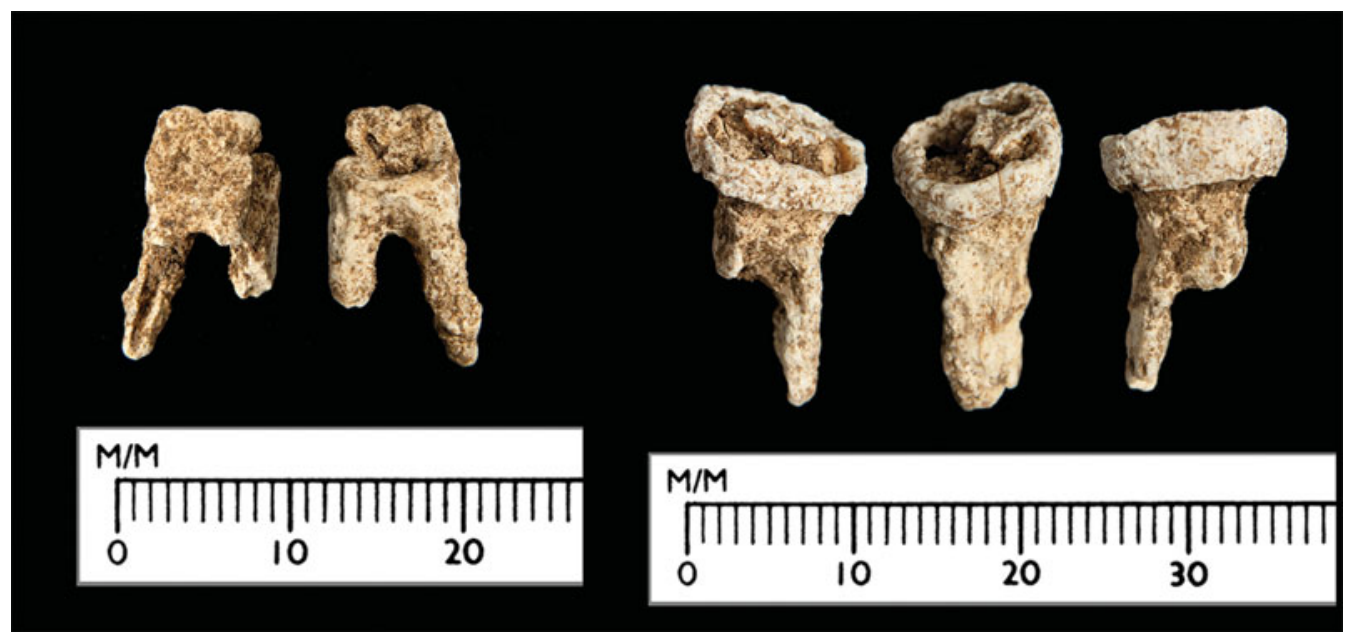

Figure 8. The Viking's teeth.

To the east, perhaps near the feet, was a broad-bladed axe (Figure 6), with part of its wooden handle preserved in mineralised form. Similar examples from a slightly later date are known from Dublin (Halpin 2008: 164). One additional set of artefacts associated with the body was a closely packed group of rivets in the east end of the boat. These appear to have been deposited together, possibly in a bag-perhaps a repair kit?

The final artefacts found in the boat, the spear and shield boss (Figure 6), were higher in the burial, deposited as part of the closure of the monument. This performative element of burial is supported by the fact that the spearhead (Petersen Type E; Petersen 1919: 26-28) was deliberately broken before being deposited. The shield appears to have been deposited with the spear and has sustained damage at the crown, and the flange is distorted (with traces of the shield board remaining), yet it remains unclear at what stage this occurred. Both items were positioned centrally, and although the stones kept them separate from the corpse, they probably corresponded with the mid to lower part of the body.

\section{The isotopes}

The two surviving teeth were micro-CT scanned to obtain a digital record prior to sampling for isotope analysis, as macroscopic preservation appeared to be poor (Figure 8). They were identified (by the internal patterns of their root canals) to be lower left first and second molars. Both enamel and dentine were present in the lower second molar, and the CT scans demonstrated that both retained the expected density and structure of modern tissues, and had potential to produce viable data.

To investigate the individual's origins, strontium, oxygen and lead isotopes, and strontium and lead concentrations were obtained from the enamel in the second molar crown, which mineralises between the ages of approximately 2 and 6 (AlQahtani et al. 2010). In addition, carbon and nitrogen isotope profiles were produced from incremental dentine samples from the same tooth following the method of Beaumont et al. (2013). These represent diet between the approximate ages of 2 and 15.

(C) Antiquity Publications Ltd, 2017 


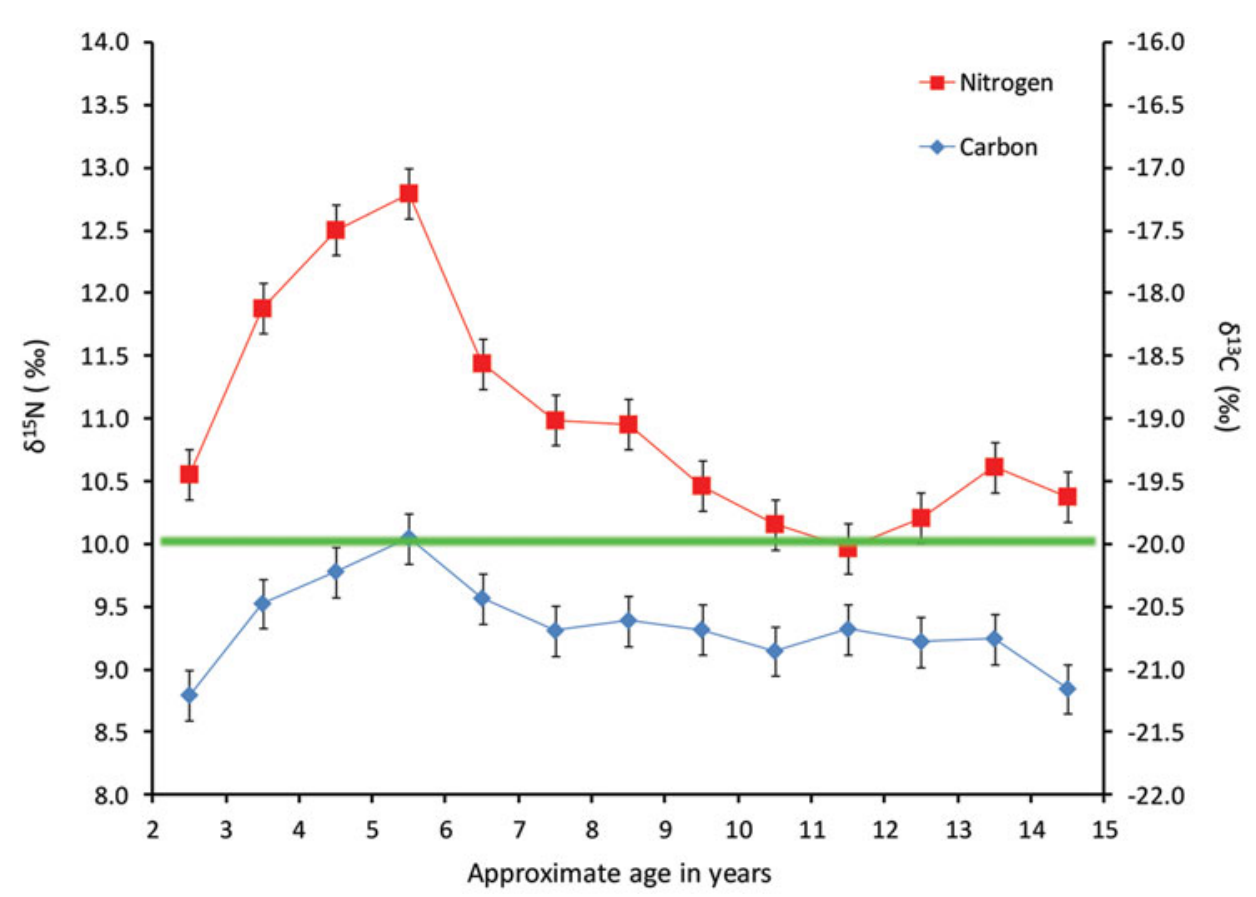

Figure 9. Plot showing the carbon and nitrogen isotope ratios against approximate age for dentine collagen extracted from the M2. The green line indicates the suggested upper limit for $\delta^{13} \mathrm{C}$ of $-20 \%$ for solely terrestrial diets in prehistoric northern Britain (Bonsall et al. 2009). Analytical uncertainty is shown at $\pm 0.2 \%$ ( $1 \sigma)$.

Results indicate that the individual consumed a largely terrestrial diet up to the age of 15 , with a period of increased marine protein consumption between the ages of 3 and 5 (Figure 9). Isotopic evidence for marine protein consumption by humans is rare in Britain in the first millennium AD, even at coastal sites (Barrett \& Richards 2004; Müldner \& Richards 2007; Müldner et al. 2009; Buckberry et al. 2014; Curtis-Summers et al. 2014), but both non-marine and marine protein consumers are found in Viking Age Norway; children appear to eat less marine protein than adults (Kosiba et al. 2007; Naumann et al. 2014). Evidence for marine consumption in childhood may indicate that the individual was living on or close to the coast.

The low oxygen isotope ratio of $16.7 \%$ shows that the Ardnamurchan individual did not originate from the place of burial on the western seaboard of Britain (Figure 10). Oxygen isotopes also rule out the Northern and Western Isles of Scotland, western Britain and western Ireland. Both the strontium and lead isotopes are indicative of origins in a region of relatively old geology, and thus rule out England and Wales, other regions of young sedimentary rocks, basalts and limestone, and Denmark, which is predominantly limestone overlain by till and hosts a strontium isotope biosphere between 0.70810.7111 (Frei \& Frei 2011). This would be difficult to reconcile with the Ardnamurchan individual's strontium isotope ratio of 0.7112 . The combined evidence, including the very low level of lead exposure experienced by the Ardnamurchan individual $(0.4 \mathrm{mg} / \mathrm{kg})$, suggests origins in a region of ancient, possibly Precambrian, geology with little or no 


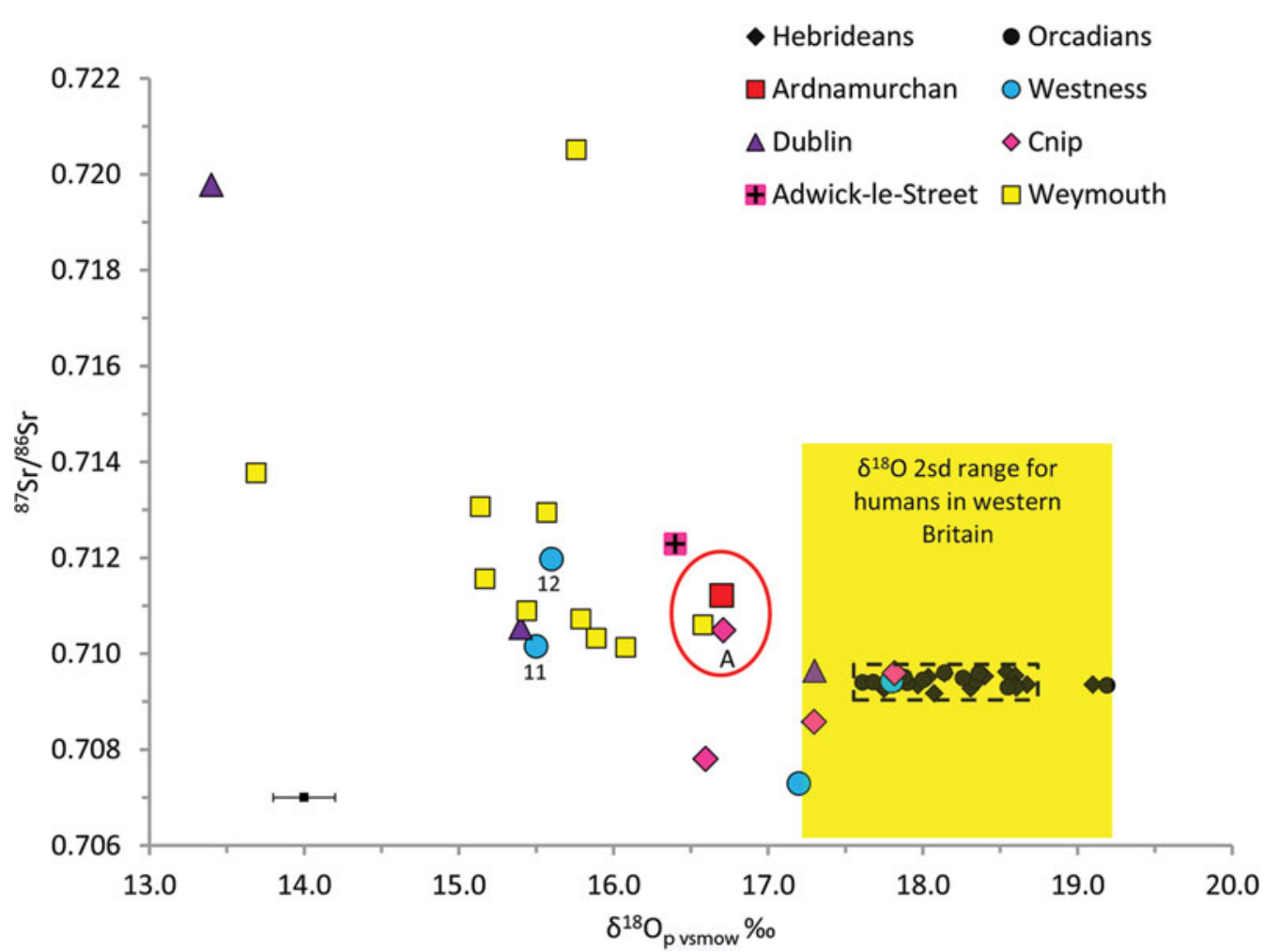

Figure 10. Enamel strontium and phosphate oxygen isotope data for the Ardnamurchan burial compared to data for other Viking-period burials in Britain and Ireland. The estimated range indicated by the yellow box for biosphere strontium in the Ardnamurchan peninsula is taken from Evans et al. (2010) and the range (again in the yellow box) of $\delta^{18}$ O for western Britain from Evans et al. (2012).

environmental lead pollution. Given that there are no significant lead deposits in Denmark, southern Norway or western Sweden (Reimann et al. 2012), and that Scandinavia lay outside the Roman Empire-which heralded the advent of increased lead levels in humans in first-millennium AD Britain (Montgomery et al. 2010)—lead levels below $0.5 \mathrm{mg} / \mathrm{kg}$ may indicate Scandinavian origins in British Viking-period burials (Montgomery et al. 2014). Places consistent with all the isotopic and trace element evidence therefore include eastern Ireland, north-eastern mainland Scotland, Norway and Sweden. Further details and contextualisation of the isotope results can be found in the accompanying online supplementary material.

\section{Materialising identities}

There is clearly much to be gained from a comparison between this boat burial and others across the Scandinavian world (see papers in Crumlin-Pedersen \& Thye 1995), both in terms of identity and the broader cosmological understandings at work. Here, however, we want to focus on this specific grave, and on what it tells us about the identity of this particular person. Identity is a matter of performance and citation (Butler 1993; for discussion of identity in archaeology, see Fowler 2010; on Viking funerals and performance,

(C) Antiquity Publications Ltd, 2017 
see Price 2010). It is performative in that it is produced through people's actions, and through their relationships with the world around them. It is not somehow intrinsically held within a person, but rather is an ongoing process of becoming through life, a process that enfolds both the body (Robb \& Harris 2013: 16-17) and material things (Harris 2016). That the dead do not bury themselves is an old archaeological maxim, but neither do the living create identity in isolation. The materiality of bodies and things-whether dead or alive-has a force that cannot be ignored when considering the production of identity. Critical here is the notion of citation, the concept that when people act in certain ways, or deposit certain material things, they bring with them connections to other places, events and people (Butler 1993: 13; Jones 2007: 80-81).

When we consider this burial, what can we say about identity? At least three terms could potentially be used to describe the deceased: 'Norse', 'warrior' and 'high status'. Evidence for the first of these comes from the boat and related connotations of travel and voyaging (cf. Williams 2014: 397); from the material culture from Scandinavia and Ireland; and from the surviving teeth. Even though a definitive place of origin cannot be proven from the isotope evidence alone, when combined with the material from the grave itself a Scandinavian homeland is suggested; Ireland cannot, however, be ruled out. The evidence for a warrior identity lies, of course, in the weapons, although this imposes a traditional assumption that grave goods belong to the deceased and directly disclose their identity. Finally, the whole assemblage - the artefacts and their elaborate interment - suggests a notion of high status. None of these categories exist as absolutes, yet they are, however, all materialised and cited through relationships expressed by the material objects in the grave. These identities also emerge in the location of a person's final resting place and reflect the relationships that person may have held with other places and other times while alive.

What about gender? We have no evidence from the body on which to assign this. Although the recovery of the sword and the wider set of grave goods might traditionally suggest that this was the burial of a man (McGuire 2016; although see McLeod 2011 for an alternative opinion), any reading remains highly interpretive. A consideration of identity rooted in notions of performativity allows us to engage with the ways in which concepts of masculinity are cited through the weapons in the grave, the absence of jewellery and so on. Whether the body itself would be biologically sexed in the present as male or female is of less importance than the kinds of identity produced through the assembled grave goods. Indeed, perhaps there are material elements here that complicate the narrative we ourselves are weaving. Sickles in burials in Scotland are more often associated with females, although in the Norwegian context Petersen (1951: 515-16) has noted a majority with males. Furthermore, new work on female Norse warriors also indicates the complexity of gender in this period (Gardela 2013). Assumptions regarding binary Norse gender categories should be approached with caution.

Beyond these major strands, we can tease out further important dimensions through which identity was performed; there are many other objects that embodied other connections, relations and possibilities for practice. The placing and treatment of specific items within different parts of the burial-the sword and axe on the left, the drinking horn on the right, the ladle behind the head-point to potential conceptual schemas or cosmologies materialised in these deliberate choices. Meanwhile, the pan, the hammer and 
tongs, the strike-a-lights and the whetstone speak to the rhythms of daily life, of cooking and work, just as the sickle links to farming and food production. The importance of repair, of the embodied work of maintaining objects and crafts, is referenced in the bag of rivets and the whetstone. These activities are important elements of the identities that are materially constructed in these acts of deposition: identities of seafaring and farming, of distant journeys and local connections, entwine with those materialised around a hot forge or a domestic hearth. The absent body is made present through the full range of relations disclosed. Similarly, while the isotopes tell us where this person grew up, they also reveal the brief period during their childhood when a marine diet dominated.

It is not only the identity of the dead that is transformed through these performative practices: places are also changed by the links constituted between Norway, the Irish Sea and Ardnamurchan through the material associations engendered in acts of deposition. Just as they speak to us of origins and connections, so these 'pieces of places' (sensu Bradley 2000: 88) created associations between Swordle Bay and the broader Norse world. They may have materialised the journeys that the deceased took in life, the narrative of their individual history (Price 2010: 147) as they travelled from Scandinavia, over the sea and round the Scottish coast, potentially meeting and trading with people from Dublin along the way. New kinds of memory and connectivity are forged, connecting migrant identities to these new places (cf. McGuire 2010: 193; 2016). We could use the stable isotope data to speculate further regarding similarities to the female burial A at Cnip (see Figure 10 and online supplementary material) that is of a similar date (Welander et al. 1987: 169). Could the occupants of these two burials, who probably grew up in close geographic and chronological proximity, have remained in contact after leaving their homeland? A degree of visual contact was certainly maintained: on a clear day, a view of the Outer Hebrides is possible from Swordle Bay.

We should also remember the other identities performed and transformed here among the people involved in digging the boat-shaped grave, dragging the boat onto the foreshore and burying it, 1000 years ago. It is all too easy to employ clinical archaeological conventions when we discuss the cut of the grave and the deposits therein; the stone lining, the deposition of the body and grave goods. Yet these are not just representative of physical 'events in time', but of bodily actions undertaken, of moments of grief and of identities performed. Those undertaking the actions, caught up in the burial, and those watching, were also changed through the memories and connections they made (Williams 2014). Price (2010) has written of the drama of Viking funerals, and we can imagine this here too. The boat set into the ground, the sword bent, the spear snapped. If the spear and shield were indeed deposited later, this suggests a different kind of relationship was being formed between these objects and the deceased, perhaps specific connections with the living that endured beyond death, the grave site facilitating 'post-funeral engagements' (Williams 2014: 404).

\section{Assembling places and persons}

In the final section, we want to consider an important question: why was this Viking buried here (cf. Williams et al. 2010)? Until very recently, both local and long-distance (C) Antiquity Publications Ltd, 2017 
movement in the region was characterised by sea travel, and Ardnamurchan's place in the wider seaways of the Outer and Inner Hebrides was highly important. The peninsula is a distinctive swathe of land encircled by islands: Mull to the south; Coll and Tiree to the west; the Small Isles of Eigg, Rum and Muck and the Isle of Skye to the north. Various other mainland peninsulas are also visible and easily accessed by sea. For people throughout the past, moving along the west coast by boat, and particularly on the well-travelled route from Scandinavia, via Orkney, to Dublin, Ardnamurchan was a natural stopping point. As we have seen, the material culture in the grave and the isotopic evidence speak to these regional connections, and the Scandinavian influence is underlined by the local place namesincluding Swordle Bay-that have a Norse connection (Bankier 2006, pers. comm.). Yet these geographic connections could apply anywhere on the peninsula; crucially, our wider work makes it possible to understand why it was here specifically, in Swordle Bay, that this burial was located, for this place enables a citation of relations that are not just geographic but temporal too. Swordle Bay has a rich and deep history of use that would have been clearly visible in medieval times. The large Neolithic chambered cairn of Cladh Aindreis saw repeated moments of intervention from the first burials around $3700 \mathrm{cal} \mathrm{BC}$ through the Bronze Age and into the start of the Iron Age (Harris et al. 2014). It is well attested that the Vikings knew of, respected, accessed, altered, and built mythology around Neolithic and Bronze Age monuments such as at Maes Howe, Orkney, where runic inscriptions and the expansion of the encircling bank suggest significant Viking interaction (Graham-Campbell \& Batey 1998: 60-61; Artelius 2013; see also McGuire 2016: 79). It seems highly probable that Cladh Aindreis was also the subject of important Viking narratives. Indeed, a Viking Age bead, Irish in type, was found in excavations of a disturbed context within the Neolithic tomb, and the archaeology (although badly damaged by post-medieval digging) suggests deliberate Viking intervention. Further potential links lie in the very stones that fill the boat burial itself, whose shape, geology and size match those from the chambered cairn just a short distance away-the nearest available source of such material.

The answer to the question 'why here?' lies in the richness of Swordle Bay. It is, of course, resource-rich in a traditional sense; it is one of the few bays on the northern coast of the peninsula that has a sheltered natural harbour, a fresh water source and good farming land. But it is also rich in a conceptual sense, with a clear and visible ancestry to which the boat burial connected. The use and reuse of older places and older sites of burial is a typical feature of Viking burials and no doubt speaks to a deliberate attempt to gain associations and connections with a new landscape, to appropriate it in new ways, and so create new links and new memories (Williams 2014: 398). This burial was therefore able at once to embody the everyday and the exotic, past and present, as well as local, national and international identities.

\section{Conclusion}

The Ardnamurchan boat burial represents the first excavation of an intact Viking boat burial by archaeologists on the UK mainland, and it makes a significant addition to our knowledge of burial practices from this period. The uncovering of such a burial also offers opportunities for multi-scalar analysis, from local and regional connections on the one 
hand, to the momentary act of depositing an object next to a body, or breaking a spear and placing it in the grave on the other. In this article, we have begun to trace some of these scales, including the connections evident to Scandinavia and Ireland in the objects, and how the isotopic profile suggests a varied history of diet and connections away from Swordle Bay. We have also touched on the way the boat burial brings together not only multiple geographic connections, but also some that cross time, reaching back into prehistory and forwards to our work as archaeologists in the present. Much more remains to be said, not least about the ritual process of the funeral and the detailed performances that took place there. Critically, when considering a burial like this, it is essential to remember that each of these objects, and each of these actions, was never isolated, but rather they emerge out of, and help to form, an assemblage that knits together multiple places, people and moments in time.

\section{Acknowledgements}

The 2011 excavations were funded by The Universities of Newcastle and Manchester and the Leverhulme Trust. The post-excavation analysis, isotopic work and conservation were funded by Viking River Cruises and the Strathmartine Trust, with the conservation being carried out by Pieta Greaves, then of AOC Archaeology, with further consultation from Will Murray of the Scottish Conservation Studio. Permission to excavate was granted by the Ardnamurchan Estate. The lead, strontium and oxygen isotope and concentration data were produced at the British Geological Survey, Keyworth, by Vanessa Pashley, Jane Evans, Simon Chenery and Hilary Sloane, and the carbon and nitrogen isotopes by Andy Gledhill at the University of Bradford. Thanks go to all of the staff and students who have worked on the project since 2006. We are also grateful to Irene Garcia Rovira for drawing Figures 4 and 5, and to the reviewers for their helpful comments.

\section{Supplementary material}

To view supplementary material for this article, please visit http://dx.doi.org/ 10.15184/ aqy.2016.222

\section{References}

AlQahtani, S.J., M.P. Hector \& H.M. Liversidge. 2010. Brief communication: the London atlas of human tooth development and eruption. American Journal of Physical Anthropology 142: 481-90. http://dx.doi.org/10.1002/ajpa.21258

Anderson, J. 1907. Ship-burial of the Viking time at Kilroan Bay, Colonsay. Proceedings of the Society of Antiquaries of Scotland 41: 443-49.

Artelius, T. 2013. Inventions of memory and meaning: examples of Late Iron Age reuse of Bronze Age monuments in south-western Sweden, in D. Fontijn, A.J. Louwen, S. Van Der Vaart \& K. Wentink (ed.) Beyond barrows: current research on the structuration and perception of the prehistoric landscape through monuments: 21-40. Leiden: Sidestone.

Askvik, H. with C.E. Batey. 2009. The whetstones: petrology and provenance, in G. Lucas (ed.) Hofstadir. Excavations of a Viking Age feasting hall in north-east Iceland: 293-96. Reykjavik: Institute of Archaeology.

(C) Antiquity Publications Ltd, 2017
Bankier, A. 2006. Norse place names in western Argyll. Unpublished MLitt dissertation, Glasgow University.

Barrett, J.H. \& M.P. Richards. 2004. Identity, gender, religion and economy: new isotope and radiocarbon evidence for marine resource intensification in early historic Orkney, Scotland, UK. European Journal of Archaeology 7: 249-71. http://dx.doi.org/10.1177/1461957104056502

BATEy, C.E. In press. Viking burials in Scotland: two 'new' boat burial finds, in V.E. Turner, O.A. Owen \& D.J. Waugh (ed.) Shetland and the Viking world: Proceedings of the 17th Viking Congress: 39-45. Lerwick: Shetland Heritage.

Batey, C.E. \& C. Paterson. 2013. A Viking burial at Balnakeil, Sutherland, in L. Webster \& A. Reynolds (ed.) Early medieval art and archaeology in the northern world. Studies in honour of James Graham-Campbell: 631-61. Leiden: Brill. 
Beaumont, J., A.R. Gledhill, J. Lee-Thorp \& J. Montgomery. 2013. Childhood diet: a closer examination of the evidence from dental tissues using stable isotope analysis of incremental human dentine. Archaeometry 55: 277-95. http: //dx.doi.org/10.1111/j.1475-4754.2012.00682.x

Bersu, G. \& D.M. Wilson. 1966. Three Viking graves in the Isle of Man. London: Society of Medieval Archaeology.

Bonsall, C., G.T. Cook, C. Pickard, K. McSweeney \& L. Bartosiewicz. 2009. Dietary trends at the Mesolithic-Neolithic transition in northwest Europe, in P. Crombé, M. Van Strydonck, J. Sergant, M. Boudin \& M. Bats (ed.) Chronology and evolution in the Mesolithic of northwest Europe: 539-62. Newcastle upon Tyne: Cambridge Scholars.

Bradley, R. 2000. An archaeology of natural places. London: Routledge.

Buckberry, J., J. Montgomery, J. Towers, G. Müldner, M. Holst, J. Evans, A. Gledhill, N. Neale \& J. Lee-Thorp. 2014. Finding Vikings in the Danelaw. Oxford Journal of Archaeology 33: 413-34. http://dx.doi.org/10.1111/ojoa.12045

Butler, J. 1993. Bodies that matter: on the discursive limits of sex. London: Routledge.

Crumlin-Pedersen, O. \& B.M. Thye (ed.). 1995. The ship as symbol in prehistoric and medieval Scandinavia. Copenhagen: Nationalmuseet.

Curtis-Summers, S., J. Montgomery \& M.O.H. Carver. 2014. Stable isotope analysis for dietary contrast between Pictish and medieval populations at Portmahomack, Scotland. Medieval Archaeology 58: 21-43. http:

//dx.doi.org/10.1179/0076609714Z.00000000030

Evans, J.A., J. Montgomery, G. Wildman \& N. Boulton. 2010. Spatial variations in biosphere ${ }^{87} \mathrm{Sr} /{ }^{86} \mathrm{Sr}$ in Britain. Journal of the Geological Society 167: 1-4. http://dx.doi.org/10.1144/0016-76492009-090

Evans, J.A., C.A. Chenery \& J. Montgomery. 2012. A summary of strontium and oxygen isotope variation in archaeological human tooth enamel excavated from Britain. Journal of Analytical Atomic Spectroscopy 27: 754-64.

Fowler, C. 2010. From identity and material culture to personhood and materiality, in D. Hicks \& M.C. Beaudry (ed.) The Oxford handbook of material culture studies: 352-85. Oxford: Oxford University Press.

FreI, K.M. \& R. FreI. 2011. The geographic distribution of strontium isotopes in Danish surface waters: a base for provenance studies in archaeology, hydrology and agriculture. Applied Geochemistry 26: 326-40. http: //dx.doi.org/10.1016/j.apgeochem.2010.12.006
Gardela, L. 2013. 'Warrior-women' in Viking Age Scandinavia? A preliminary archaeological study. Analecta Archaeologica Ressoviensia 8: 273-340.

Graham-Campbell, J. \& C.E. Batey. 1998. Vikings in Scotland: an archaeological survey. Edinburgh: Edinburgh University Press.

Greaves, P. 2011. Appendix six: conservation report, in O.J.T. Harris, H. Cobb, H. Gray \& P. Richardson, Viking boat burial, Swordle Bay, Ardnamurchan: season six, 2011: archaeological excavations data structure report (Ardnamurchan Transitions Report Number 17). Unpublished report prepared for the Ardnamurchan Transitions Project.

Halpin, A. 2008. Weapons and warfare in Viking and medieval Dublin. Medieval Dublin excavations 1962-81. Dublin: National Museum of Ireland.

Harris, O.J.T. 2016. Becoming post-human: identity and the ontological turn, in E. Pierce, A. Russell, A. Maldonado \& L. Campbell (ed.) Creating material worlds: theorising identity in archaeology: 17-37. Oxford: Oxbow.

Harris, O.J.T., H. Сobb, H. Gray \& P. Richardson. 2012. A Viking at rest: new discoveries on Ardnamurchan. Medieval Archaeology 56: 333-39.

- 2014. New radiocarbon dates from Cladh Aindreis chambered tomb, Ardnamurchan. Past: the Newsletter of the Prehistoric Society 76: 5-6.

Jones, A. 2007. Memory and material culture. Cambridge: Cambridge University Press. http://dx.doi.org/10.1017/CBO9780511619229

Kosiba, S.B., R.H. Түкот \& D. Carlsson. 2007. Stable isotopes as indicators of change in the food procurement and food preference of Viking Age and Early Christian populations on Gotland (Sweden). Journal of Anthropological Archaeology 26: 394-411. http://dx.doi.org/10.1016/j.jaa.2007.02.001

McGuire, E.H. 2010. Manifestations of identity in burial: evidence from Viking Age graves in the North Atlantic diaspora. Unpublished PhD dissertation, University of Glasgow.

- 2016. Move along: migrant identities in Scandinavian Scotland, in E. Pierce, A. Russell, A. Maldonado \& L. Campbell (ed.) Creating material worlds: theorising identity in archaeology: 63-85. Oxford: Oxbow.

McLeod, S. 2011. Warriors and women: the sex ratio of Norse migrants to eastern England up to 900 AD. Early Medieval Europe 19: 332-53. http: //dx.doi.org/10.1111/j.1468-0254.2011.00323.x 
Montgomery, J., S.R. Chenery, V. Pashley \& K. Killgrave. 2010. 'Gleaming, white and deadly': the use of lead to track human exposure and geographic origins in the Roman period in Britain, in H. Eckardt (ed.) Roman diasporas: archaeological approaches to mobility and diversity in the Roman Empire: 199-226. Portsmouth (RI): Journal of Roman Archaeology.

Montgomery, J., V. Grimes, J. Buckberry, J. Evans, M.P. Richards \& J.H. BarRetT. 2014. Finding Vikings with isotope analysis-the view from wet and windy islands. Journal of the North Atlantic 7: 54-70. http://dx.doi.org/10.3721/ 037.002.sp705

MüLDNER, G. \& M.P. RichaRds. 2007. Stable isotope evidence for 1500 years of human diet at the City of York, UK. American Journal of Physical Anthropology 133: 682-97. http://dx.doi.org/10.1002/ajpa.20561

Müldner, G., J. Montgomery, G. CoOK, R. Ellam, A. GLEDHILl \& C. Lowe. 2009. Isotopes and individuals: diet and mobility among the medieval Bishops of Whithorn. Antiquity 83: 1119-33. http://dx.doi.org/10.1017/ S0003598X00099403

Naumann, E., T.D. Price \& M.P. Richards. 2014. Changes in dietary practices and social organization during the pivotal Late Iron Age period in Norway (AD 550-1030): isotope analyses of Merovingian and Viking Age human remains. American Journal of Physical Anthropology 155: 322-31. http://dx.doi.org/10.1002/ajpa.22551

Nissan, K. 1999. The textile remains, in O. Owen \& M. Dalland (ed.) Scar: a Viking boat burial on Sanday, Orkney: 109-12. East Linton: Tuckwell.

Owen, O. \& M. Dalland. 1999. Scar: a Viking boat burial on Sanday, Orkney. East Linton: Tuckwell.
Paterson, C., A.J. Parsons, R.M. Newman, N. Johnson \& C. Howard Davis. 2014. Shadows in the sand. Excavation of a Viking-Age cemetery at Cumwhitton, Cumbria. Lancaster: Oxford Archaeology North.

Petersen, J. 1919. De Norske Vikingesverd: en Typologogisk-kronologisk Studie over Vikingetidens Vaaben. Kristiania [Oslo]: Jacob Dybwad.

- 1951. Vikingetidens Redskaper. Oslo: Det Norske Videnskaps-Akademi.

Price, N. 2010. Passing into poetry: Viking-Age mortuary drama and the origins of Norse mythology. Medieval Archaeology 54: 123-56. http://dx.doi.org/10.1179/ $174581710 X 12790370815779$

Reimann, C., B. Flem, K. Fabian, M. Birke, A. Ladenberger, P. Négrel, A. Demetriades, J. Hoogewerff \& Team TGP. 2012. Lead and lead isotopes in agricultural soils of Europe-the continental perspective. Applied Geochemistry 27: 532-42. http: //dx.doi.org/10.1016/j.apgeochem.2011.12.012

Roвb, J. \& O.J.T. Harris. 2013. The body in history: Europe from the Palaeolithic to the future. Cambridge: Cambridge University Press.

Welander, R.D.E., C.E. Batey \& T.G. Cowie. 1987. A Viking burial from Kneep, Uig, Isle of Lewis. Proceedings of the Society of Antiquaries of Scotland 117: 149-74.

Williams, H. 2014. Memory through monuments: movement and temporality in Skamby's boat graves, in $\mathrm{H}$. Alexandersson, A. Andreeff \& A. Bünz (ed.) Med hjärta och hjärna: En Vänbok till professor Elisabeth Arwill-Nordbladh: 397-413. Gothenburg: University of Gothenburg.

Williams, H., M. Rundkvist \& A. Danielsson. 2010. The landscape of a Swedish boat-grave cemetery. Landscapes 11: 1-24. http://dx.doi.org/10.1179/lan.2010.11.1.1

Received: 11 January 2016; Accepted: 21 April 2016; Revised: 2 June 2016

(C) Antiquity Publications Ltd, 2017 